\title{
PERSEPSI MASYARAKAT MUSLIM PONOROGO DALAM MEMILIH JASA PERBANKAN SYARIAH
}

\author{
Naning Kristiyana ${ }^{1}$, Adi Santoso ${ }^{2}$ \\ ${ }^{1}$ Universitas Muhammadiyah Ponorogo, Email: nrafakristi@gmail.com, \\ ${ }^{2}$ Universitas Muhammadiyah Ponorogo, Email : $\underline{\text { adisantoso@umpo.ac.id }}$
}

\begin{abstract}
ABSTRAK
Penelitian Persepsi Masyarakat Muslim Ponorogo Dalam Memilih Jasa Perbankan Syariah ini mempunyai tujuan antara lain untuk mengetahui persepsi masyarakat muslim Ponorogo terhadap Bank Syariah dan untuk mengetahui transaksi keuangan yang dilakukan masyarakat muslim Ponorogo. Penelitian ini dilakukan di Kabupaten Ponorogo dengan menggunakan metode penelitian diskriptif kuantitatif. Populasinya adalah dosen STAIN dan FAI Unmuh Ponorogo. Sampel dalam penelitian ini adalah 75 responden. Pengumpulan data primer dilakukan dengan kuisioner. Analisis data di lapangan menggunakan format deskriptif kuantitatif. Persepsi dosen STAIN Ponorogo dan Fakultas Agama Islam Ponorogo terhadap bank syariah adalah baik. Hal ini dapat terlihat dari perilaku konsumen / perilaku responden yang dipengaruhi oleh faktor tingkat pendidikan sebagian besar adalah sarjana strata dua / S2, faktor budaya melalui budaya Islami dalam lingkungan kerja STAIN dan Unmuh Ponorogo, serta stimulus dari pengetahuan akan produk syariah yang menghasilkan persepsi sebagai umpan balik dari stimulus tersebut. Transaksi keuangan yang dilakukan oleh responden sebagian besar atau $63 \%$ responden menggunakan jasa bank konvensional dan bank syariah, sedangkan yang murni hanya menggunakan jasa keuangan syariah saja hanya 11 responden dari kseleuruhan jumlah responden. Hasil penelitian ini menemukan bahwa nasyarakat muslim di Ponorogo menggunakan jasa bank konvensional dan syariah tersebut berdasarkan aturan dari instansi tempat bekerja.
\end{abstract}

Kata Kunci: Persepsi; Pendidikan; Budaya; Bank Syariah

\begin{abstract}
This study "Perceptions of Ponorogo Muslim Communities in Selecting Sharia Banking Services" aims to find out among other things the perception of the Ponorogo Muslim community on Islamic Banks and to find out the financial transactions carried out by the Ponorogo Muslim community. This research was conducted in Ponorogo Regency by using a quantitative descriptive research method. The population is STAIN and FAI Unmuh Ponorogo lecturers. The sample in this study was 75 respondents. Primary data collection is done by questionnaire. Data analysis in the field uses a quantitative descriptive format. The perception of STAIN Ponorogo and Ponorogo Islamic Religion lecturers on Islamic banks is good. This can be seen from the consumer behavior / respondent behavior that is influenced by education level factors, most of them are bachelor degree / S2, cultural factors through Islamic culture in STAIN and Unmuh Ponorogo work environment, and stimulus from knowledge of sharia products that produce perceptions as bait behind the stimulus. Most of the financial transactions conducted by respondents or $63 \%$ of respondents use the services of conventional banks and Islamic banks, while those who purely use Islamic financial services only 11 respondents from the total number of respondents. The results of this study found that the Muslim community is using the services of conventional and sharia banks based on regulations from the workplace agencies.
\end{abstract}

Keywords: Perception; Education; Culture; Islamic Banks 


\section{PENDAHULUAN}

Lembaga keuangan perbankan memiliki fungsi strategis sebagai lembaga intermediasi dan memberikan jasa dalam lalu lintas pembayaran. Intermediasi keuangan ini memberikan peranan pokok dalam proses pengalihan dana sehingga mampu meningkatkan perekonomian. Proses pengalihan dana ini merupakan proses pembelian surplus dana dari unit ekonomi baik sektor usaha, pemerintah maupun rumah tangga, untuk disalurkan kepada unit ekonomi defisit. Selain itu bank juga memiliki peran yang teramat penting karena sebagai lembaga yang dapat mempengaruhi kegiatan perekonomian melalui kemampuan bank dalam meningkatkan atau mengurangi daya beli dalam perekonomian. Kegiatan usaha perbankan dapat dibagi menjadi dua yaitu bank konvensional dan bank syariah. Ketentuan sistem perbankan syariah secara umum diatur dalam Undang-undang Nomor 10 Tahun 1998, dimana bank umum adalah bank yang melaksanakan kegiatan usaha secara konvensional dan atau berdasarkan prinsip syariah yang dalam kegiatannya memberikan jasa dalam laulintas pembayaran. Sedangkan Bank Perkreditan Rakyat adalah bank yang melaksanakan kegiatan usaha secara konvensional atau berdasarkan prinsip syariah yang dalam kegiatannya tidak memberikan jasa dalam lalulintas pembayaran.

Bank syariah memiliki peran yang sama dengan bank konvensional meskipun memiliki karakter tersendiri namun diharapkan dapat saling melengkapi dan memberikan pelayanan kepada masyarakat yang belum bersedia memanfaatkan jasa-jasa bank konvensional serta untuk memobilisasi dana masyarakat yang selama ini belum terlayani oleh sistim perbankan konvensional. Yang dimaksud bank syariah (Siamat, 2004: 183) secara umum adalah bank yang dalam menjalankan usahanya berdasarkan prinsip-prinsip hukum syariah Islam dengan mengacu pada Al Qur'an dan al hadist. Sedangkan prinsip syariah menurut Undang-undang Nomor 10 Tahun 1998 adalah aturan perjanjian berdasarkan hukum Islam antara bank dan pihak lain untuk menyimpan dana dan atau pembiayaan kegiatan usaha atau kegiatan lainnya yang dinyatakan sesuai dengan syariah, antara lain pembiayaan berdasarkan prinsip bagi hasil (mudharabah), pembiayaan berdasarkan prinsip penyertaan modal (musharakah), prinsip jual beli barang (murabahah) atau pembiayaan barang modal berdasar prinsip sewa murni (ijarah) atau adanya pilihan pemindahan kepemilikan atas barang yang disewa dari pihak bank oleh pihak lain (ijarah waiqtina). Perbankan syariah memberikan layanan bebas bunga kepada para nasabahnya. Pembayaran dan penarikan bunga dilarang dalam semua bentuk transaksi. Islam melarang kaum muslim menarik atau membayar bunga (riba). Pelarangan inilah yang membedakan sistem perbankan syariah dengan sistem perbankan konvensional. 
Bank Umum Syariah (BUS) telah mencapai 12 unit dan Unit Usaha Syariah (UUS) mencapai 22 unit berdasar data Mei 2015. Memang jumlah ini tidak ada perubahan sejak 2013. Namun, jumlah jaringan kantor mengalami penurunan. Jika pada bulan Desember 2013 jumlah kantor mencapai 163 unit, pada bulan Mei 2015 jumlah ini berkurang menjadi 162 unit. Adanya pengurangan jumlah jaringan kantor tentu saja menjadikan jumlah pengguna bank syariah menurun (Statistik Perbankan Syariah, Mei 2015).

Ponorogo sebagai salah satu kabupaten di Jawa Timur, mayoritas masyarakat adalah muslim dan memiliki cukup banyak pondok pesantren dengan satu pondok pesantren terbesar di Indonesia yaitu Pondok Modern Gontor. Kenyataan bahwa masyarakat Ponorogo dikenal masyarakat santri yang seharusnya memegang teguh nilai-nilai agama dan dipraktekan dalam seluruh aktivitas kehidupan serta kenyataan bahwa Ponorogo memiliki pondok pesantren yang tersebar antara lain di wilayah Kecamatan Siman, Kecamatan Mlarak, Kecamatan Jetis, dan wilayah lainnya melatar belakangi usulan penelitian ini. Selain pondok pesantren Ponorogo juga memiliki Perguruan Tinggi Swasta dan Negeri Islam seperti ISID (Institut Studi Islam Darussalam), Universitas Muhammadiyah, dan STAIN (Sekolah Tinggi Agama Islam Negeri).

Banyaknya pondok pesantren dan perguruan tinggi Islam diharapkan kegiatan perbankan syariah di Ponorogo semakin pesat dengan berbagai jasa layanan syariahnya. Tetapi kegiatan perbankan syariah di Ponorogo kenyataannya belum menunjukan kemajuan yang pesat terbukti kantor cabang ataupun kantor pembantu bank syariah masih sedikit. Ternyata bank syariah masih belum menjadi pilihan utama masyarakat dalam melakukan transaksi keuangan. Bank Muamalat saja yang terbilang sudah cukup lama beroperasi di Ponorogo, baru sekitar dua tahun terakhir ini ada Bank Syariah Mandiri beroperasi di Ponorogo.

Syarat bank umum membuka jaringan kantor bank dengan membuka cabang menurut Surat Edaran Bank Indonesia Nomor .15/7/DPNP tanggal 8 Maret 2013 antara lain yaitu pembukaan jaringan kantor bisa dilakukan apabila Bank telah menyalurkan kredit kepada Usaha Mikro, Kecil dan Menengah (UMKM) paling rendah 20\% dan atau $10 \%$ dari total portofolio kredit. Hal ini menunjukkan bahwa jumlah nasabah yang menggunakan jasa perbankan syariah di Ponorogo masih relatif kecil yaitu belum mencapai 10\% sehingga Bank BRI Syariah, Bank BNI Syariah belum membuka cabang di Ponorogo. Fenomena ini jelas bertentangan dengan ekspektasi yang tertulis dalam Blueprint of Islamic Banking Development in Indonesia yang dipublikasikan Bank Indonesia pada tahun 2002. Dalam jangka pendek, tantangan yang mesti dihadapi oleh bank syariah adalah (1) penyediaan sumber daya insani (SDI); secara kuantitas 
maupun kualitas; (2) inovasi pengembangan produk dan layanan perbankan syariah yang kompetitif dan berbasis kekhususan kebutuhan masyarakat; dan (3) kontinuitas program sosialisasi dan edukasi kepada masyarakat.

\section{TINJAUAN PUSTAKA}

\section{Bank Syariah}

Irbid dan Zarka (2001) dalam penelitian dengan judul "Identifikasi Faktor Penentu Keputusan Konsumen Dalam memilih Jasa Perbankan, Bank Syariah atau Bank Konvensional" memberikan kesimpulan bahwa faktor yang mendorong nasabah memilih bank syariah cenderung didasarkan motif keuntungan bukan didasarkan dari motif keagamaan.

Institut Pertanian Bogor (2004) melakukan survey di Kalimantan Selatan tentang persepsi bank konvensional, menunjukkan bahwa 94,5\% responden setuju dengan peranan bank konvensional dengan alasan menguntungkan masyarakat dan permodalan. Diperoleh pula hasil sebesar 79,3\% responden menyatakan sistim bunga bank konvensional bertentangan dengan ajaran agama. Namun disisi lain mereka adalah nasabah bank konvensional. Implikasi hasil penelitian di atas memperlihatkan bahwa persepsi tentang perilaku konsumen dalam hal ini nasabah perbankan menjadi semakin krusial dan perlu untuk diteliti.

Konsep bank syariah sebutan umum untuk bank Islam adalah bank syariah. Menurut ensiklopedia Islam, bank Islam adalah lembaga keuangan yang usaha pokoknya memberikan kredit dan jasa-jasa dalam lalu lintas pembayaran serta peredaran uang yang pengoperasiannya disesuaikan dengan prinsip-prinsip Islam. Sedangkan menurut Undang-Undang Nomor 21 Tahun 2008 pasal 1 ayat (1) tentang Perbankan Syariah, disebutkan bahwa bank syariah adalah segala sesuatu yang menyangkut tentang bank syariah, mencakup kelembagaan, kegiatan usaha, serta cara dan proses dalam melaksanakan kegiatan usahanya. Dalam pasal 1 ayat (7) Undang-Undang Nomor 21 Tahun 2008 tentang Perbankan Syariah disebutkan bahwa bank syariah adalah Bank yang menjalankan kegiatan usahanya berdasarkan Prinsip syariah dan menurut jenisnya terdiri atas Bank Umum Syariah dan Bank Pembiayaan Rakyat Syariah. Pasal 1 ayat (12) menyebutkan bahwa prinsip syariah adalah prinsip hukum Islam dalam kegiatan perbankan berdasarkan fatwa yang dikeluarkan oleh lembaga yang memiliki kewenangan dalam penetapan fatwa di bidang syariah (Sumitro, 2004).

Perbankan syariah memberikan layanan bebas bunga kepada para nasabahnya. Pembayaran dan penarikan bunga dilarang dalam semua bentuk transaksi. Islam melarang kaum muslim menarik atau membayar bunga (riba). Pelarangan inilah yang 
membedakan sistem perbankan syariah dengan sistem perbankan konvensional. Meskipun sebelumnya terjadi perdebatan mengenai apakah riba ada kaitannya dengan bunga (interest) atau tidak, namun sekarang nampaknya ada konsensus dikalangan ulama bahwa istilah riba meliputi segala bentuk bunga.

Penolakan atas bunga ini memunculkan pertanyaan tentang apa yang dapat menggantikan mekanisme penerapan suku bunga dalam sebuah kerangka kerja Islam. Jika pembayaran dan penarikan bunga dilarang, bagaimana bank-bank syariah? Di sinilah sistem profit-and-loss-sharing (bagi-untung-dan-rugi) digunakan sebagai metode alokasi sumberdaya. Meskipun banyak sekali bentuk kontrak dalam permodalan Islam, namun ada beberapa jenis transaksi yang penting: mudharabah (kontrak permodalan); musyarakah (kontrak kemitraan atau partnership); dan metode mark-up (penarikan harga).

Mudharabah merupakan kontrak profit-and-loss-sharing dimana satu pihak memercayakan sejumlah modal kepada seorang investor dengam imbalan memperoleh suatu bagian yang telah ditentukan dari keuntungan atau kerugian bisnis yang di modali. Sedangkan dalam musyarakah, biasanya terdapat lebih dari satu penyandang dana; semua pihak menginvestasikan dananya dengan proporsi yang beragam, dan keuntungan atau kerugiannya ditanggung bersama sesuai dengan kontribusi mereka dalam bisnis itu. Musyarakah membutuhkan kemitraan yang lebih aktif dari pihak-pihak yang menggabungkan modalnya dan mengelola serta mengontrol perusahaan bersamasama. Sementara keuntungan dan kerugian ditanggung bersama sesuai dengan rasio yang ditetapkan sebelumnya. Apabila kita tambahkan kepada dua model ini ide 'mark-up', yang memiliki banyak sekali varian, dimana aset-aset dan barang-barang yang diperoleh kemudian dijual kembali atau disewa-belikan dengan harga yang di-mark-up, maka kita mempunyai ramuan utama dari alternatif islami untuk bank yang menjalankan operasi sistem bunga (Lewis dan Latifa, 2005:11-14).

Berikut ini adalah perbandingan antara bank syariah dengan bank konvensional:

Tabel 1: Perbandingan Antara Bank Syariah dan Bank Konvensional

\section{Bank Syariah}

1. Melakukan investasi-investasi yang halal saja.

2. Berdasarkan prinsip bagi hasil, jual-beli atau sewa.

3. Profit dan falah oriented.

4. Hubungan dengan nasabah dalam bentuk hubungan kemitraan.

5. Penghimpunan dan penyaluran dana harus sesuai dengan fatwa Dewan Pengawas Syariah.

\section{Bank Konvensional}

1. Investasi yang halal dan haram.

2. Memakai perangkat bunga.

3. Profit oriented.

4. Hubungan dengan nasabah dalam bentuk hubungan debitor-debitor.

5. Tidak terdapat dewan sejenis. 


\section{Dasar Perbankan Syariah \\ Larangan Riba}

Riba secara literal berarti tambahan, berkembang, atau tumbuh. Akan tetapi tidak setiap tambahan atau pertumbuhan itu dilarang oleh Islam. Dalam syariah, riba secara teknis mengacu kepada pembayaran premi yang harus dibayarkan oleh peminjam kepada pemberi pinjaman disamping pemgembalian pokok sebagai syarat pinjaman atau perpanjangan batas jatuh tempo (Chapra, 2000: 21-22). Karim (2004: 56-57) menjelaskan bahwa riba telah menjadi bahan perdebatan sejak zaman kaum muslim yang paling awal. Umar bin Khattab, khalifah kedua, menyesalkan karena Nabi Muhammad saw. wafat sebelum sempat memberikan penjelasan yang terperinci mengenai pengertian riba. Di kalangan orang barat, istilah usury pada umumnya sekarang dipakai untuk menyebut bunga yang 'terlalu tinggi' atau 'berlebih-lebihan'. Tetapi dalil Al Quran menyatakan bahwa semua bentuk bunga harus dikutuk: Tetapi jika kamu bertobat, maka bagi kamu jumlah pokoknya [yakni modal] (Q.S. al-Baqarah: 279). Atas dasar hal tersebut, para ulama berpendapat bahwa riba meliputi tidak hanya usury, tetapi semua jenis bunga. Ini mengingatkan kepada argumen-argumen dari para sarjana barat abad pertengahan yang menyatakan bahwa semua bunga itu berlebihan.

\section{Perilaku Konsumen}

Dalam manajemen pemasaran perilaku konsumen merupakan perilaku tentang bagaimana individu, kelompok dan organisasi memilih, membeli, menggunakan barang dan jasa untuk memuaskan kebutuhan dan keinginan konsumen sehingga konsumen akan mengambil suatu keputusan pembelian. Konsumen diberi rangsangan pemasaran melalui kesadarannya, sebelum melakukan keputusan pembelian. Perilaku konsumen dipengaruhi oleh beberapa faktor. Menurut Kotler (2002 : 183) faktor-faktor yang mempengaruhi perilaku konsumen faktor budaya, faktor sosial, faktor pribadi, dan faktor psikologis.

\section{Teori Pengambilan Keputusan}

\section{Pengertian Keputusan Pembelian}

Pengambilan keputusan sebagai suatu kelanjutan dari cara pemecahan masalah setidaknya memiliki dua fungsi pokok. Pertama, pangkal permulaan dari semua aktivitas manusia yang sadar dan terarah baik secara individual maupun secara kelompok, baik secara institusional maupun secara organisasional. Kedua, sesuatu yang bersifat futuristik, artinya bersangkut paut dengan hari depan, masa yang akan datang, dimana efek atau pengaruhnya berlangsung cukup lama. Hasan (2002:11) dalam Toni Prasetyo menjelaskan bahwa, dalam pengambilan keputusan hendaknya harus dipahami empat unsur-unsur atau komponen-komponen dari sebuah pengambilan keputusan: (1) Tujuan dari pengambilan keputusan; (2) Identifikasi alternatif-alternatif keputusan untuk 
memecahkan masalah; (3) Perhitungan mengenai faktor-faktor yang tidak dapat diketahui sebelumnya/di luar jangkauan manusia; (4) Sarana atau alat untuk mengevaluasi atau mengukut hasil dari suatu pengambilan keputusan.

Seseorang yang menerima rangsangan tersebut akan memberikan persepsi sebagai umpan balik dari situasi tertentu. Persepsi menurut Kotler (2002: 198) adalah proses yang digunakan oleh seseorang individu untuk memilih, mengorganisasi dan menginterpretasi masukan-masukan informasi guna menciptakan gambaran yang memiliki arti. Persepsi tidak hanya bergantung pada rangsangan fisik tetapi juga ranmgsangan yang berhubungan dengan lingkungan sekitar dan keadaan individu yang bersangkutan.

Persepsi yang akan dinyatakan oleh seseorang dalam menerima rangsangan sebelum seseorang melakukan perilaku pembelian, dipengaruhi oleh beberapa hal (Kotler, 2002: 182) adalah:

1. Faktor Budaya, budaya merupakan penentu yang paling fundamental dalam membentuk keinginan dan perilaku seseorang.

2. Faktor Sosial, seperti kelompok referensi, keluarga, status, dan peranan sosial dalam masyarakat.

3. Faktor Pribadi, karakteristik kepribadian yang berbeda-beda mempengaruhi terhadap tingkah lakunya.

4. Faktor Psikologis, pilihan pembelian/konsumsi seseorang secara psikologis dipengaruhi oleh motivasi, pembelajaran serta keyakinan.

Persepsi dapat juga diartikan sebagai proses kognitif yang dialami oleh setiap orang dalam memahami setiap informasi tentang lingkungannya, baik dengan penglihatan, pendengaran, penghayatan, perasaan dan penciuman. Dengan kata lain persepsi dapat dirumuskan sebagai proses yang kompleks dan menghasilkan suatu gambaran tentang kenyataan yang sangat berbeda dengan kenyataan sebelumnya. Persepsi merupakan suatu reaksi terhadap situasi keseluruhan dari suatu lingkungan atau keseluruhan stimulus. Menurut Mozkowits dalam Desriani (1993), persepsi memiliki hirarkhi sebagai berikut: 1) Gambaran dasar, 2) Bentuk dan pola, 3) Konteks, 4) Identifikasi, 5) Bersifat motivasi.

\section{Proses Keputusan Pembelian}

Menurut Philip Kotler (2004:204-211), dalam sebuah pembelian, konsumen melewati lima tahapan yaitu:

a. Pengenalan Produk

Proses pembelian dimulai saat pembeli mengenali sebuah masalah atau kebutuhan. Kebutuhan tersebut dapat dicetuskan oleh rangsangan internal atau eksternal. Sebuah 
perusahaan perlu mengidentifikasikan keadaan yang memicu kebutuhan tertentu. Dengan mengumpulkan informasi dari sejumlah konsumen, perusahaan dapat mengidentifikasi rangsangan yang paling sering membangkitkan strategi pemasaran yang memicu minat konsumen.

b. Pencarian Informasi

Konsumen yang tergugah kebutuhannya akan terdorong untuk mencari informasi yang lebih banyak. Situasi pencarian informasi ini terbagi menjadi dua tingkat. (1) perhatian yang menguat, pada tingkat ini seseorang hanya peka terhadap ingormasi tentang produk. (2) pencarian aktif informasi, pada tingkat ini seseorang akan mencari bahan bacaan, menelpon teman, dan mengunjungi toko untuk mempelajari produk. Sumber informasi konsumen digolongkan menjadi empat yaitu sumber pribadi, sumber komersial, sumber publik, dan sumber pengalaman.

c. Evaluasi Alternatif

Dalam tahap evaluasi, konsumen akan memproses informasi produk yang bersaing dan membuat penilaian. Beberapa konsep dasar dalam proses evaluasi konsumen dapat di paparkan menjadi tiga bagian. Pertama, konsumen berusaha untuk memenuhi suatu kebutuhan. Kedua, konsumen mencari manfaat tertentu dari solusi produk. Ketiga, konsumen memandang masing-masing produk sebagai sekumpulan atribut dengan kemampuan yang berbeda-beda dalam memberikan manfaat yang digunakan untuk memuaskan kebutuhan.

d. Keputusan Pembelian

Keputusan konsumen untuk menunda atau menghindari suatu keputusan pembelian sangat dipengaruhi oleh resiko yang dirasakan (perceived risk). Besarnya risiko yang dirasakan berbeda menurut uang yang dipertaruhkan, besarnya ketidakpastian atribut, dan besarnya kepercayadirian konsumen.

e. Perilaku Pasca Pembelian

Setelah membeli produk, konsumen akan mengalami tahap berikutnya yaitu kepuasan pasca pembelian, tindakan pasca pembelian dan pemakaian produk pasca pembelian. Para pelanggan yang puas akan terus melakukan pembelian; para pelanggan yang tidak puas akan menghentikan pembelian produk yang bersangkutan dan kemungkinan akan menyebarkan berita buruk tersebut ke teman-teman mereka. Oleh karena itu, perusahaan harus berusaha memastikan tercapainya kepuasan konsumen pada semua tingkat dalam proses pembelian.

\section{METODE PENELITIAN}

\section{Lokasi dan Populasi}

Penelitian ini dilakukan di STAIN dan Universitas Muhammadiyah Ponorogo terhadap dosen dan karyawannya. Populasi penelitian ini adalah seluruh dosen dan 
karyawan STAIN dan Unmuh Ponorogo. Menurut Creswell (2008) dalam Herdiansyah (2010); Populasi adalah suatu kelompok individu yang memiliki karakteristik yang sama atau relatif serupa. Neuman (2000) dalam Herdiansyah (2010) mendefinisikan populasi sebagai suatu kelompok besar dari kesatuan sampel.

\section{Sampel}

Neuman (2000) pada Herdiansyah (2010); Sampel adalah bagian dari populasi yang akan dilibatkan dalam penelitian, merupakan bagian yang representatif dan mempresentasikan karakter atau ciri-ciri dari populasi. Penelitian ini ditinjau dari sumber data yang dijadikan subyek penelitian termasuk penelitian sampel.

Tehnik pengambilan sampel yang digunakan dalam penelitian ini adalah tehnik random sampling, yaitu dengan memberi peluang yang sama untuk setiap anggota populasi untuk terpilih menjadi sampel. Strategi sampling yang dipilih adalah typikal sampling (Herdiansyah, 2010) yaitu suatu strategi yang digunakan untuk kasus-kasus yang bersifat khas atau unik atau individu-individu yang memiliki karakteristik yang unik. Sedangkan sampling insidental merupakan teknik penentuan sampel berdasarkan kebetulan, yaitu siapa saja yang secara kebetulan/insidental bertemu peneliti dapat digunakan sebagai sampel, bila dipandang orang yang kebetulan ditemui cocok sebagai sumber. Gudono (2012) menegaskan bahwa jumlah observasi dalam regresi logistik minimal adalah 100. Sehingga jumlah sampel yang digunakan dalam penelitian ini adalah 75 orang dosen.

Sesuai dengan tujuan penelitian ini, maka metode analisis data dengan menggunakan metode analisis deskriptif kuantitatif, yaitu peneliti menampilkan angka-angka, gambar atau tabel yang dapat menggambarkan dan menjelaskan kondisi riil lapangan berdasarkan hasil pengumpulan data. Penelitian kuantitatif dengan format deskriptif menurut Bungin (2005: 36) bertujuan untuk menjelaskan, meringkaskan berbagai kondisi, berbagai situasi atau berbagai variable yang timbul di masyarakat yang menjadi obyek penelitian itu berdasarkan apa yang terjadi. Kemudian mengangkat ke permukaan karakter atau gambaran tentang kondisi, situasi ataupun variable tersebut.

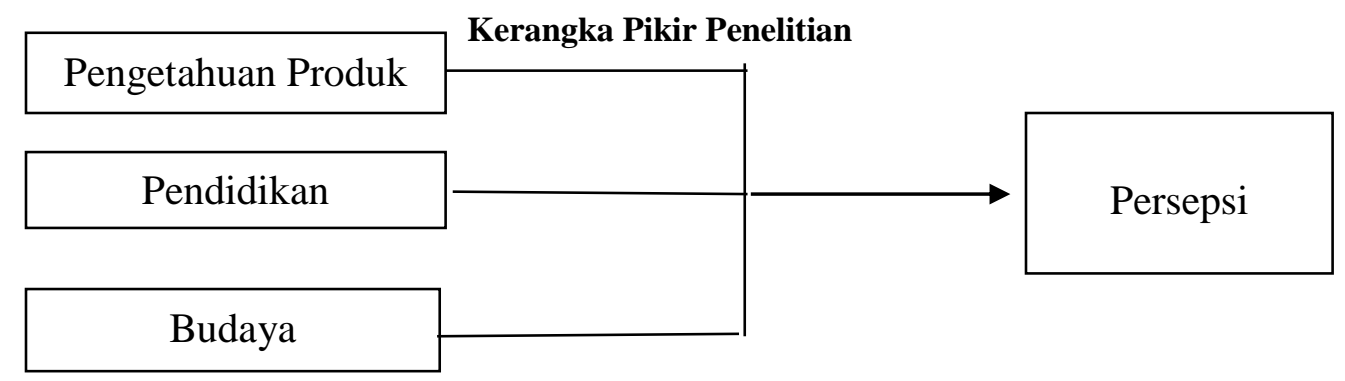

Gambar 1. Kerngka Pikir Penelitian 


\section{HASIL PENELITIAN DAN PEMBAHASAN}

Untuk meningkatkan efisiensi, efektivitas, dan kualitas pendidikan di IAIN, maka dipandang perlu melakukan penataan terhadap fakultas-fakultas di lingkungan IAIN yang berlokasi di luar IAIN induk. Berdasarkan Keputusan Presiden Republik Indonesia Nomor 11 Tahun 1997 Tentang Pendirian Sekolah Tinggi Agama Islam Negeri, maka semua fakultas di lingkungan IAIN yang berlokasi di luar induk, berubah menjadi Sekolah Tinggi agama Islam Negeri (STAIN) dan tidak lagi menjadi bagian dari IAIN. STAIN bersifat otonom (berdiri sendiri) dan merupakanunit organik tersendiri di lingkungan Departemen Agama yang dipimpin oleh Ketua yang bertanggung jawab kepada Menteri Agama. Pembinaan STAIN secara fungsional dilakukan oleh Direktorat Jendral Kelembagaan Agama Islam Departemen Agama. STAIN mempunyai tugas pembinaan perguruan tinggi Agama Islam swasta di wilayahnya melalui badan Kopertais.

STAIN Ponorogo merupakan salah satu dari Fakultas daerah, yaitu Fakultas Syari'ah IAIN Sunan Ampel di Ponorogo, yang dialih statuskan menjadi Sekolah Tinggi Agama Islam Negeri. STAIN Ponorogo yang berdiri sejak tanggal 21 Maret 1997 M, bertepatan dengan tanggal 12 Dzulqaidah $1417 \mathrm{H}$. Dengan perubahan status tersebut, maka STAIN Ponorogo dapat membuka tiga Jurusan yaitu: Jurusan Syari'ah, Jurusan Tarbiyah, dan Jurusan Ushuluddin.

Fakultas Agama Islam Universitas Muhammadiyah Ponorogo memiliki visi menjadi pusat kajian dan pengembangan Ilmu Kependidikan Islam yang berkualitas dalam melahirkan sarjana sebagai kader persyarikatan yang profesional dibidangnya, misi yang ingin dilakukan oleh FAI Unmuh Ponorogo antara lain : Mempersiapkan dan meningkatkan sumber daya manusia pendidik Islam untuk mewujudkan dakwah persyarikatan, mengembangkan ilmu-ilmu kependidikan Islam dengan mempertimbangkan problem kekinian umat Islam dan kemajuan Iptek. FAI Unmuh Ponorogo memiliki prodi Pendidikan Agama Islam dan Pendidikan Guru Madrasah Ibtidaiyah (PGMI).

\section{Transaksi Keuangan Responden}

Berdasarkan Gambar 5.5 mengenai transaksi keuangan yang dilakukan responden menunjukkan bahwa sebanyak $15 \%$ atau 11 responden menjadi nasabah bank syariah, 16\% atau 12 responden menjadi nasabah bank konvensional, dan 69\% atau 52 responden menjadi nasabah bank syariah dan konvensional. 


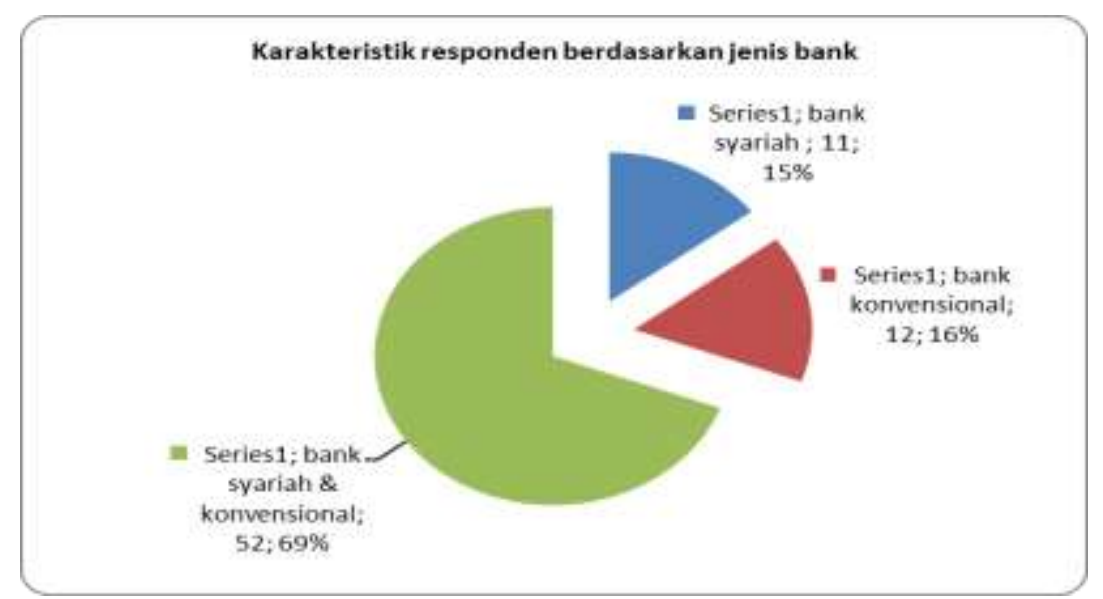

Gambar 2. Transaksi Keuangan Responden

\section{UJI INSTRUMEN PENELITIAN}

Data-data yang diperoleh setelah penelitian di lapangan adalah berupa data-data tentang persepsi masyarakat terhadap Bank Syariah. Data tersebut diperoleh dengan menyebarkan angket yang dijawab oleh responden dan telah dikembalikan pada peneliti. Jumlah sampel sebanyak 75 orang. Sampel penelitian berasal dari 2 Universitas di Ponorogo yaitu Universitas Muhammadiyah Ponorogo dan Sekolah Tinggi Agama Islam Negeri STAIN Ponorogo.

Adapun deskripsi data hasil pengolahan komputer dengan program SPSS versi 20 adalah sebagai berikut:

1. Uji Validitas Data

Uji validitas dilakukan untuk mengetahui tingkat kemampuan suatu instrumen atau alat pengumpul data dalam mengungkap sesuatu yang menjadi sasaran pokok pengukuran yang dilakukan. Hasil perhitungan validitas berdasar Lampiran 1 menunjukkan bahwa 8 indikator pada variable Persepsi dinyatakan valid karena karena mempunyai nilai pearson correlation yang lebih besar dari $r$ tabel $(0,227)$ dan nilai signifikansi yang kurang dari nilai alpha $(0,05)$ sehingga variable persepsi dapat digunakan untuk pengujian tahap selanjutnya.

2. Uji Reliabilitas Data

Uji reliabilitas diperlukan untuk mengetahui tingkat keajegan alat ukur yang dipakai. Pengujian reliabilitas terhadap seluruh indikatoruntuk 2 variabelyang digunakan pada penelitian ini akan menggunakan formula Cronbach Alpha (Koefisien CronbachAlpha), dimana secara umum dianggap reliabel apabila nilai CronbachAlpha> 0,6. Sesuai hasil pengujian reliabilitas dengan menggunakan 
program SPSS versi 20 diperoleh hasil sesuai tabel berikut:

Tabel 2. Hasil Pengujian Reliabilitas

\begin{tabular}{cccc}
\hline No & Variabel & Cronbach Alpha & Hasil \\
\hline 1 & Variabelpersepsi & 0.781 & Reliabel \\
2 & Variabelpengetahuanproduk & 0.884 & Reliabel \\
\hline & Sumber : Hasil Pengujian Reliabilitas. Lampiran 3 atau Reliability.
\end{tabular}

Nilai reliabilitas ditunjukkan dalam tabel, untuk kedua koefisien Cronbach Alfa dinyatakan reliabel karena lebih besar dari 0,6. Dengan demikian semua indikator pada kedua variable yaitu variable persepsi dan pengetahuan dalam penelitian dinyatakan reliabel dan selanjutnya dapat digunakan dalam penelitian.

\section{Deskripsi Variabel Persepsi}

Pada bagian ini didiskripsikan data hasil kuesioner yang telah dibagikan. Terdapat 8 indikator persepsi terhadap Bank Syariah. Jawaban responden untuk masing-masing indikator pada variable persepsi dapat dilihat pada Gambar 3 sampai dengan 10 .

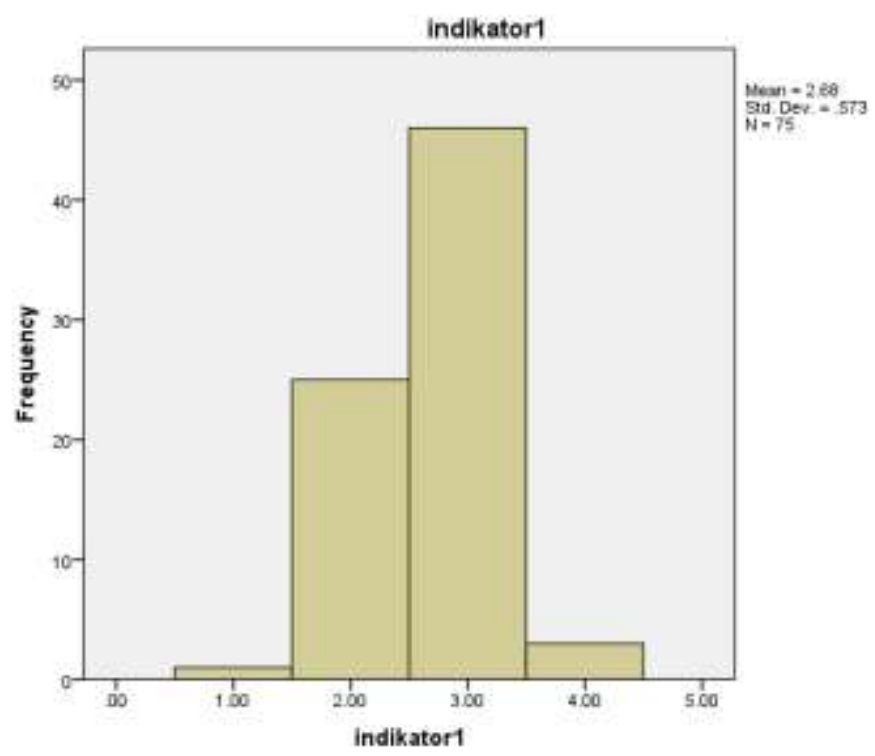

Gambar 3. Histogram Indikator 1

Berdasarkan Gambar 5.6 dapat dilihat bahwa skor tertinggi adalah 3 yang berarti bahwa sebagian besar keluarga responden banyak yang memilih menjadi nasabah bank syariah. 


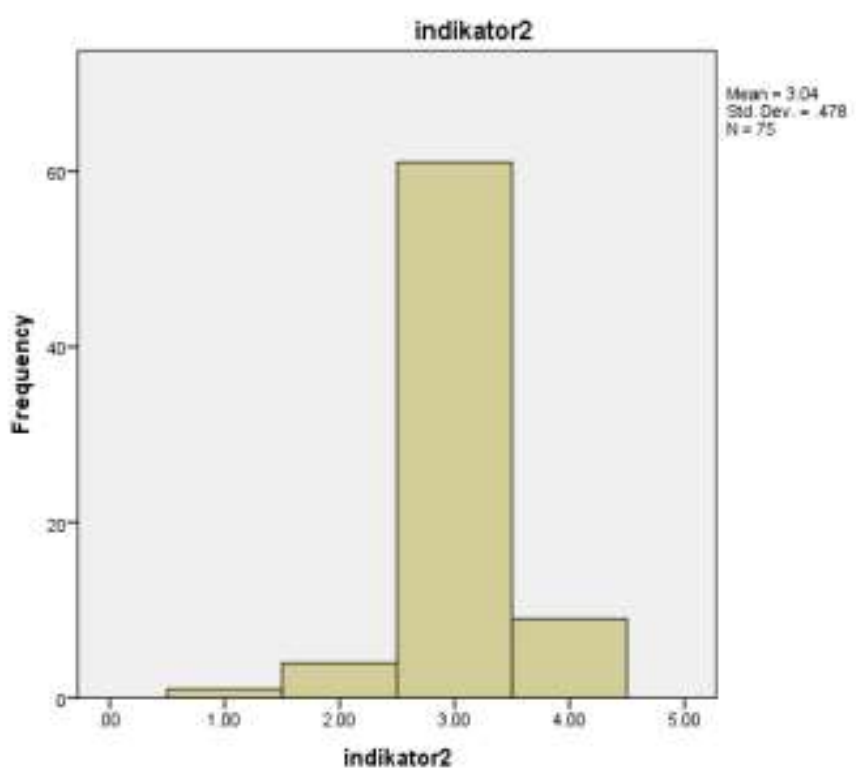

Gambar 4. Histogram Indikator 2

Berdasarkan Gambar 4 dapat dilihat bahwa skor tertinggi adalah 3 yang berarti bahwa sebagian besar responden setuju bahwa bank syariah merupakan bank yang Islam.

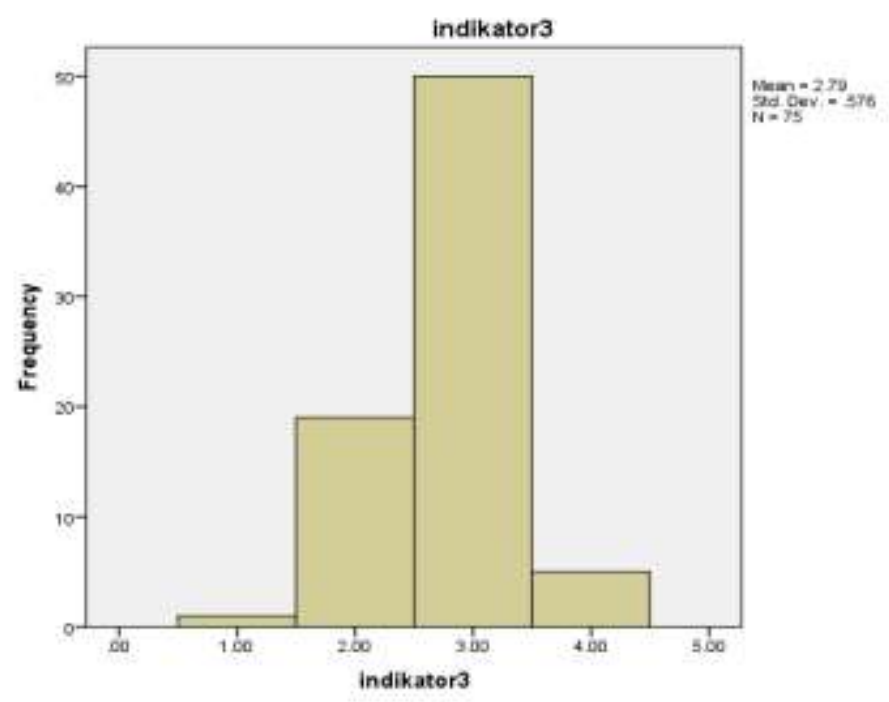

Gambar 5. Histogram Indikator 3

Berdasarkan Gambar 5 dapat dilihat bahwa skor tertinggi adalah 3 yang berarti bahwa sebagian besar responden percaya bahwa dengan menggunakan bank syariah akan membawa selamat dunia dan akhirat. 


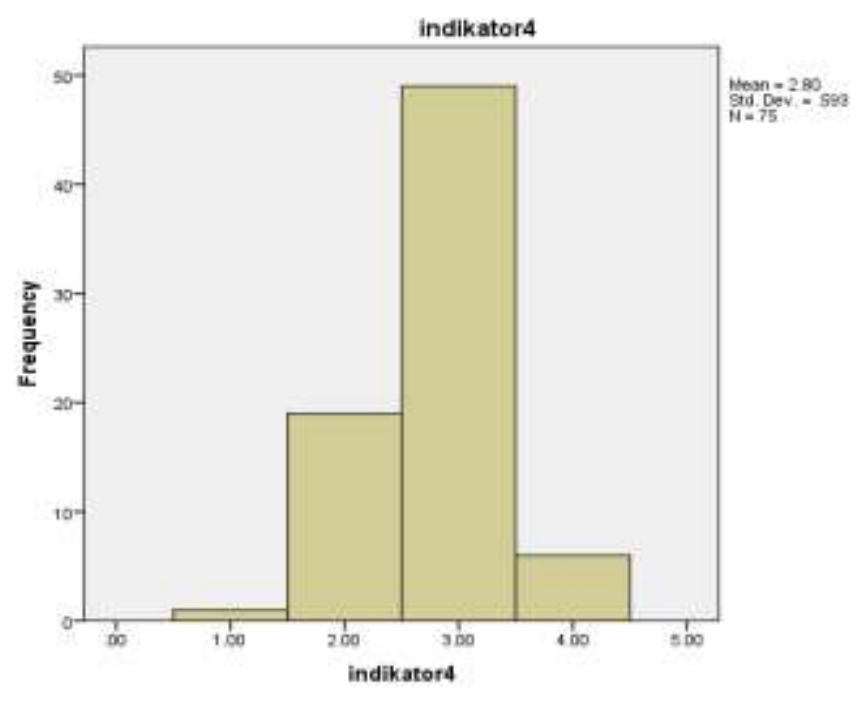

Gambar 6. Histogram Indikator 4

Berdasarkan Gambar 6 dapat dilihat bahwa skor tertinggi adalah 3 yang berarti bahwa sebagian besar responden memilih bank syariah karena adanya fatwa MUI yang mengharamkan bunga bank.

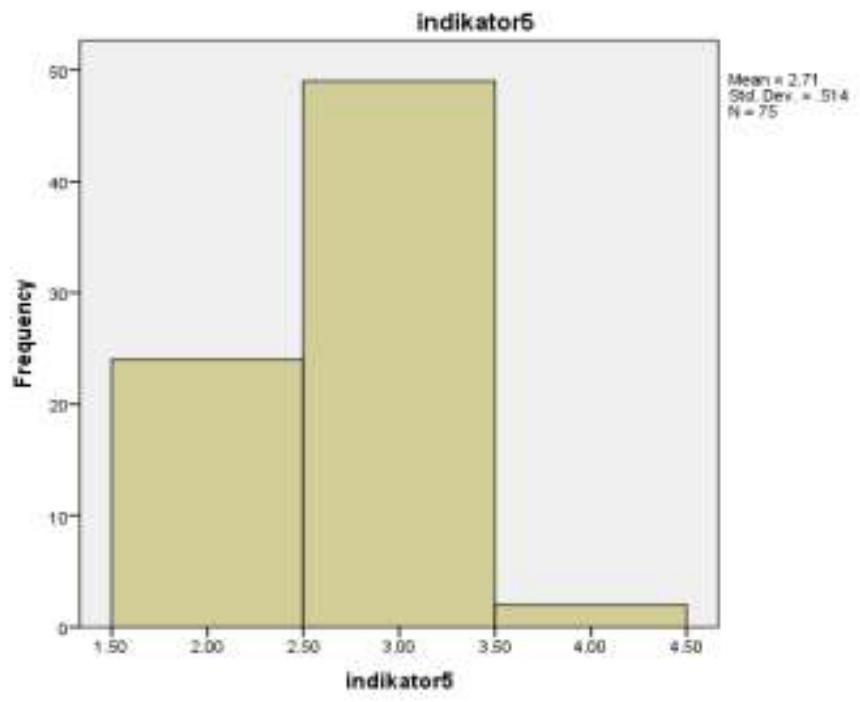

Gambar 7. Histogram Indikator 5

Berdasarkan Gambar 7 dapat dilihat bahwa skor tertinggi adalah 3 yang berarti bahwa sebagian besar responden setuju bahwa bank syariah merupakan salah satu bank yang memperoleh tingkat kepercayaan yang baik dari masyarakat. 


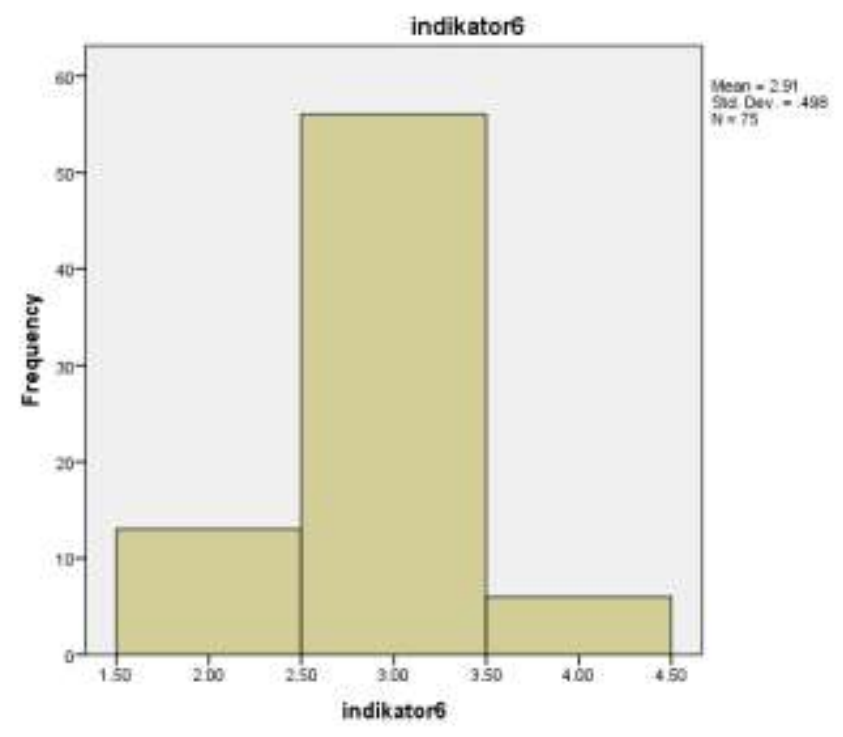

Gambar 8. Histogram Indikator 6

Berdasarkan Gambar 8 dapat dilihat bahwa skor tertinggi adalah 3 yang berarti bahwa sebagian besar responden setuju bahwa bank syariah lebih menguntungkan dan lebih adil secara ekonomi.

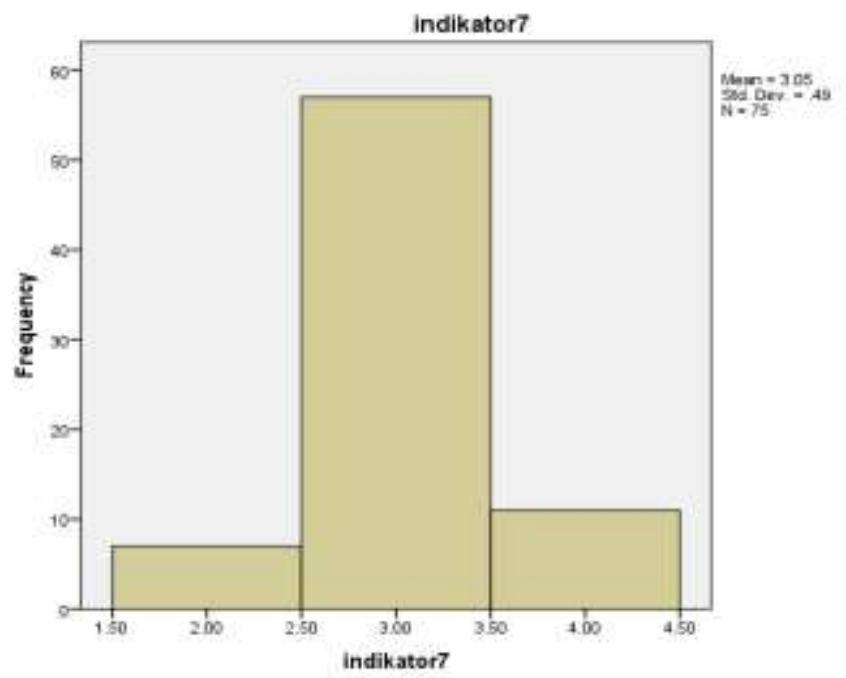

Gambar 9. Histogram Indikator 7

Berdasarkan Gambar 9 dapat dilihat bahwa skor tertinggi adalah 3 yang berarti bahwa sebagian besar responden setuju bahwa sistim bagi hasil adalah sistim universal dan dapat diterima karena bersifat menguntungkan baik bank maupu nmasyarakat. 


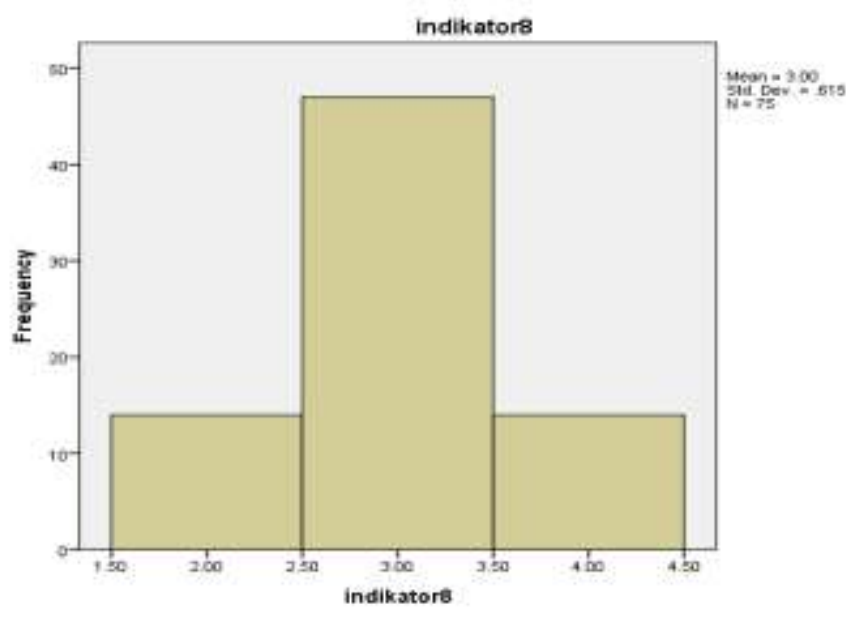

Gambar 10. Histogram Indikator 8

Berdasarkan Gambar 10 dapat dilihat bahwa skor tertinggi adalah 3 yang berarti bahwa sebagian besar responden yakin bahwa dengan menggunakan bank syariah akan berdampak positif terhadap kegiatan sehari-hari.

\section{Deskripsi Variabel Pengetahuan Produk}

Pada bagian ini dideskripsikan data hasil kuesioner yang telah dibagikan. Terdapat 4 indikator yaitu indikator 9-12. Jawaban yang diberikan responden tersebut secara tidak langsung mencerminkan pengetahuan responden tentang produk. Jawaban responden untuk masing-masing indicator pada variable pengetahuan produk dapat di lihat pada Gambar 11 sampai dengan 14.

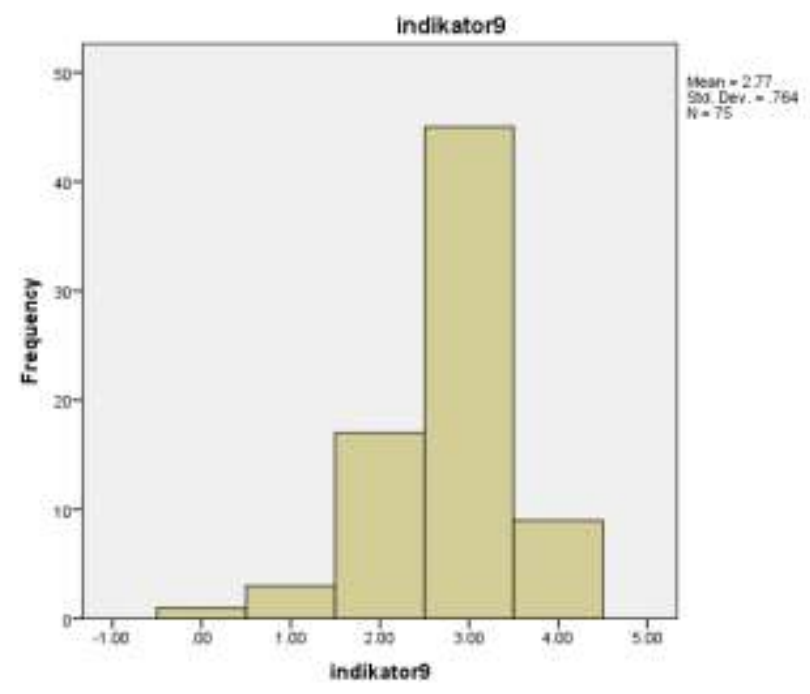

Gambar 11. Histogram Indikator 9

Berdasarkan Gambar 11 dapat dilihat bahwa skor tertinggi adalah 3 yang berarti 
bahwa sebagian besar responden mempunyai pengetahuan tentang fatwa bunga bank dengan baik.

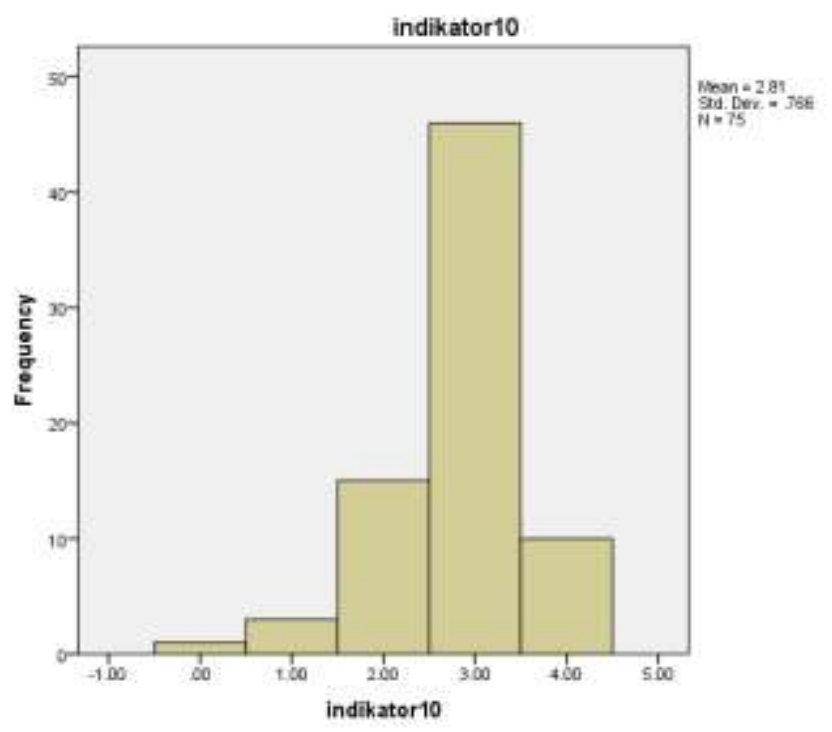

Gambar 12. Histogram Indikator 10

Berdasarkan Gambar 12 dapat dilihat bahwa skor tertinggi adalah 3 yang berarti bahwa sebagian besar responden telah mengetahui tentang prinsip mudharabah pada bank syariah.

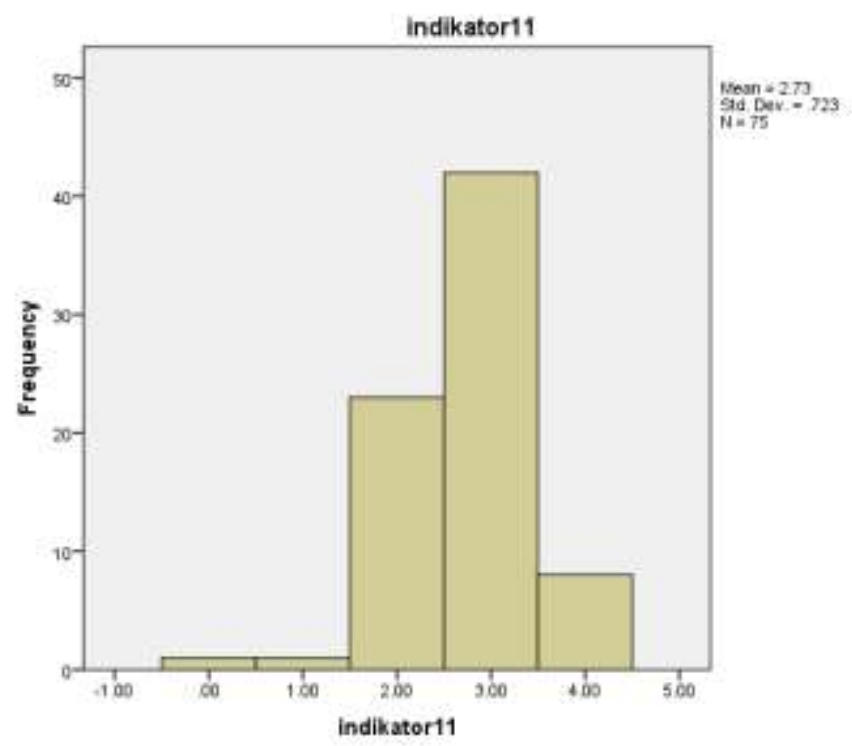

Gambar 13. Histogram Indikator 11

Berdasarkan Gambar 13 dapat dilihat bahwa skor tertinggi adalah 3 yang berarti 
bahwa sebagian besar responden telah mengetahui tentang prinsip musyarakah pada bank syariah dengan baik.

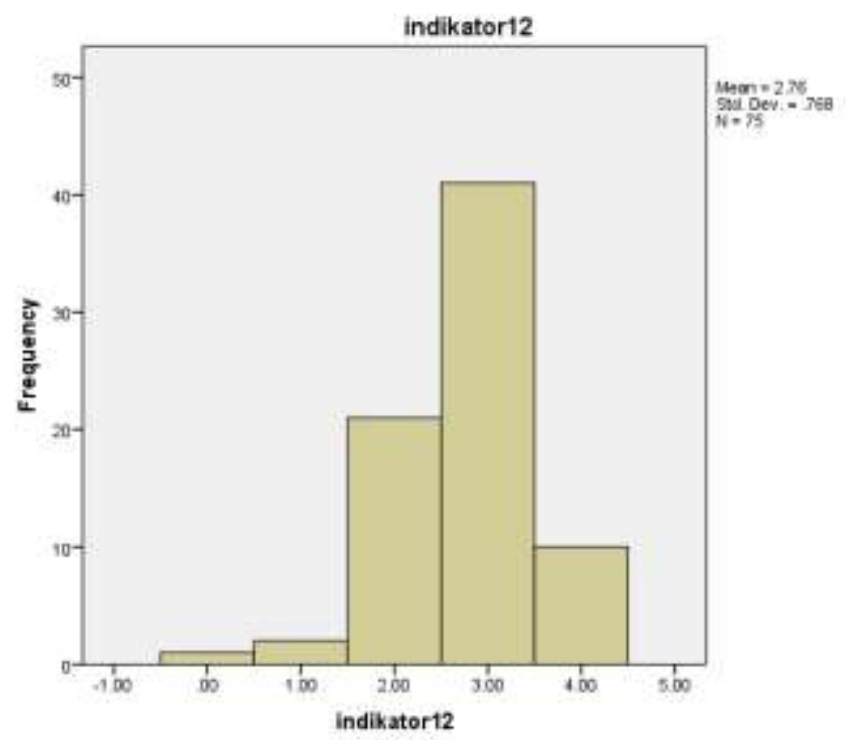

Gambar 14. Histogram Indikator 12

Berdasarkan Gambar 14 dapat dilihat bahwa skor tertinggi adalah 3 yang berarti bahwa sebagian besar responden telah mengetahui tentang prinsip murabahah pada bank syariah.

\section{PEMBAHASAN}

Variabel Pengetahuan Produk

Pengetahuan produk yang dinyatakan dalam prinsip-prinsip bank syariah seperti prinsip mudharabah, prinsip musyarakah, dan prinsip murabahah telah dipahami sebagian besar responden. Hal ini terjadi karena responden bekerja pada lingkungan kerja Islami.

Variabel Pendidikan

Berdasarkan Gambar 5.3 mengenai karakteristik responden berdasarkan pendidikan terakhir menunjukkan bahwa sebanyak 5\% atau 4 responden mempunyai tingkat pendidikan terakhir sebagai sarjana (S1), 83\% atau 63 responden berpendidikan S2 , 12\% atau 9 responden berpendidikan S3 dan tidak ada responden yang berpendidikan terakhir D3.

Variabel Budaya

Lingkungan budaya STAIN Ponorogo dan Fakultas Agama Islam Ponorogo adalah agama Islam yang meyakini syariah Islam sebagai prinsip dalam kehidupan 
responden. Alasan responden memilih jasa keuangan yang diambil sebagai berikut:

Tabel 3. Alasan Responden Memilih Jasa Keuangan

\begin{tabular}{llcc}
\hline No. & \multicolumn{1}{c}{ Alasan memilih } & Jumlah & Prosentase \\
\hline 1. & Mengetahui syariah Islam & 19 & $25 \%$ \\
2. & Aturan dari instansi tempat bekerja & 27 & $36 \%$ \\
3. & $\begin{array}{l}\text { Diajak suami/istri, keluarga, saudara, } \\
\text { teman }\end{array}$ & 2 & $3.4 \%$ \\
& $\begin{array}{l}\text { Lebih menguntungkan untuk investasi \& } \\
\text { transaksi keuangan }\end{array}$ & 22 & $29 \%$ \\
4. & & \\
& $\begin{array}{l}\text { LAIN-LAIN: } \\
\text { Mudah dijumpai (konvensional) }\end{array}$ & 5 & $6.6 \%$ \\
$\quad \begin{array}{l}\text { Prosedur gampang (konvensional) } \\
\text { Terlanjur (konvensional) }\end{array}$ & & \\
$\quad \begin{array}{l}\text { Mencoba (syariah) } \\
\text { Jumlah }\end{array}$ & 75 & $100 \%$ \\
\hline
\end{tabular}

Sumber: data primer diolah

Variabel Persepsi

Berdasarkan hasil deskripsi variable diatas persepsi dosen STAIN Ponorogo dan Fakultas Agama Islam Ponorogo terhadap bank syariah adalah baik. Hal ini dapat terlihat dari perilaku konsumen/perilaku responden yang dipengaruhi oleh factor tingkat pendidikan sebagian besar adalah sarjana strata dua /S2, faktor budaya melalui budaya Islami dalam lingkungan kerja STAIN dan Unmuh Ponorogo, serta stimulus dari pengetahuan akan produk syariah yang menghasilkan persepsi sebagai umpan balik dari stimulus tersebut. Persepsi yang akan dinyatakan oleh responden dalam menerima rangsangan sebelum seseorang melakukan perilaku pembelian memutuskan menggunakan jasa keuangan syariah atau tidak.

Transaksi keuangan yang dilakukan oleh responden sebagian besar atau $63 \%$ responden menggunakan jasa bank konvensional dan bank syariah, sedangkan yang murni hanya menggunakan jasa keuangan syariah saja hanya 11 responden dari kseleuruhan jumlah responden. Hal ini menjadi fenomena baru yang ditemukan dalam penelitian ini dan responden menggunakan jasa bank konvensional dan syariah tersebut berdasarkan aturan dari instansi tempat bekerja.

\section{SIMPULAN}

Persepsi dosen STAIN Ponorogo dan Fakultas Agama Islam Ponorogo terhadap bank syariah adalah baik. Hal ini dapat terlihat dari perilaku konsumen/perilaku responden yang dipengaruhi oleh faktor tingkat pendidikan sebagian besar adalah sarjana strata dua /S2, factor budaya melalui budaya Islami dalam lingkungan kerja 
STAIN dan Unmuh Ponorogo, serta stimulus dari pengetahuan akan produk syariah yang menghasilkan persepsi sebagai umpan balik dari stimulus tersebut. Persepsi yang akan dinyatakan oleh responden dalam menerima rangsangan sebelum seseorang melakukan perilaku pembelian memutuskan menggunakan jasa keuangan syariah atau tidak.

Transaksi keuangan yang dilakukan oleh responden sebagian besar atau $63 \%$ responden menggunakan jasa bank konvensional dan bank syariah, sedangkan yang murni hanya menggunakan jasa keuangan syariah saja hanya 11 responden dari kseleuruhan jumlah responden. Hal ini menjadi fenomena baru yang ditemukan dalam penelitian ini dan responden menggunakan jasa bank konvensional dan syariah tersebut berdasarkan aturan dari instansi tempat bekerja.

Bank syariah dalam strategi pemasarannya agar lebih melakukan kerjasama dengan pihak instansi-instansi sehingga misi dan visi syariah dapat tersampaikan kepada masyarakat melalui instansi tempat bekerja mereka. Bank syariah hendaknya meningkatkan sosialisasi syariah ke semua instansi di Ponorogo, atau kelompok/organisasi masyarakat sehingga masyarakat semakin "familiar" tentang prinsip-prinsip syariah dalam manajemen perbankan syariah.

\section{DAFTAR PUSTAKA}

Arikunto, Suharsimi, 2002, Prosedur Peneiltian, Rineka Cipta, Jakarta

Abu Muhammad Dwiono K.A, 2012, Selamat Tinggal Bank Konvensional, CV Tifa Surya Indonesia, Jakarta.

Antonio, M. Syafi i. 2001. Bank Syariah: Dari Teori ke Praktik. Jakarta: Gema Insani Press

Burhan Bungin, Prof., Dr., S.Sos. M.Si, 2005, Metodologi Penelitian Kuantitatif, Penerbit Prenada Media, Jakarta.

Dahlan Siamat, 2004, Manajemen Lemabaga Keuangan Edisi Keempat, Fakultas Ekonomi Universitas Indonesia, Jakarta.

Blueprint Of Islamic Banking Development in Indonesia , 2002

Chapra, M. Umer. 2000. Sistem Moneter Islam. Terjemahan Ikhwan Abidin B. Jakarta: Gema Insani Press.

Karim, Adiwarman. 2004. Bank Islam: Analisis Fiqih dan Keuangan. Jakarta: Raja Grafindo Persada.

Kotler, Philip, 2009, Manajemen Pemasaran, Jilid 1, Edisi 13, Erlangga, Jakarta

Shinta, Agustina, 2011, Manajemen Pemasaran, Universitas Brawijaya Press, Malang 
Bank Indonesia, 2015, Statistik Perbankan Syariah Mei 2015

Sugiyono. 2008. Metode Penelitian Kuantitatif, Kualitatif dan R\&D. Bandung: Alfabeta.

Sumitro, Warkum. 2004. Asas-Asas Perbankan Islam dan Lembaga-Lembaga Terkait (Bamui, Takaful dan Pasar Modal Syariah) di Indonesia. Jakarta: Raja Grafindo Persada.

Lewis, Mervyn K. dan Latifa M. Algaoud. 2005. Perbankan Syariah: Prinsip, Praktik dan Prospek. Terjemahan Burhan Wirasubrata. Jakarta: Serambi Ilmu Semesta.

Gudono. 2012. Analisis Multivariat. Yogyakarta: BPFE

Indriantoro, Nur dan Bambang Supomo, 2002, Metodologi Penelitian Bisnis Untuk Akuntansi dan Manajemen, Edisi Pertama, BPFE Yogyakarta.

Surat Edaran Bank Indonesia Nomor 15/7/DPNP Tanggal 8 Maret 2013 Tentang Pembukaan Jaringan Kantor Bank.

Toni Prasetyo Utomo, 2014, Analisis Faktor-Faktor Yang Mempengaruhi Keputusan Nasabah Dalam Memilih Jasa Perbankan Syariah, Skripsi, Universitas Brawijaya Malang.

Undang-Undang Nomor 10 Tahun 1998 Tentang Perbankan

Undang-Undang Nomor 21 Tahun 2008 Tentang Bank Syariah 